\section{Review of a Modern Technical Solution in Continuous Miner Machine Technology}

\author{
Arkadiusz Mężyk, Mariusz Pawlak \\ Jan Kania, Wojciech Klein \\ Silesian University of Technology, Poland
}

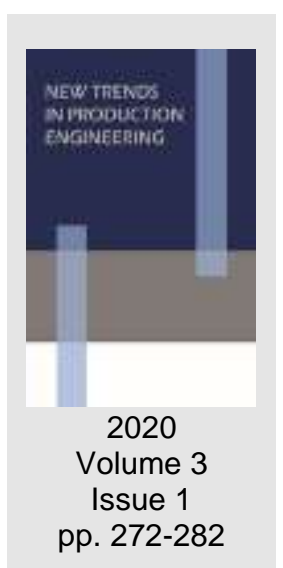

Date of submission to the Editor: 02/2020

Date of acceptance by the Editor: 03/2020

\title{
INTRODUCTION
}

Continuous mining excavators are the machines, with the milling head whose size is strictly correlated to the course or tunnel width. The boom with the head installed on them is usually moving in swinging motion only in a vertical plane. The entire header width is active during cutting, and to increase the size of excavation are used two approaches. The miner is changing its position to a new place, or the cutting unit is rotated in a horizontal plane to excavate further deposits.

The Continuous Miner is standard continuous excavator; the Bolter Miner has additional roof bolts. These machines are used for the extraction of coal, salt, potassium or gypsum deposits, as well as for preparatory work and tunnel drilling in stone (ANON,1995, p. A121; Balci, 2009, p. 423; McFeat-Smith, 1987, p. 254; Graham, 1996, p. 213).

This technology is the most popular in USA, RSA, Australia and China.

The first patent claims for constructions of this type appeared at the turn of the $19^{\text {th }}$ and $20^{\text {th }}$ centuries. An example is the structure proposed by Franz Pawel in the patent application of September 11, 1902 (Fig. 1) (Pawel).

According to the market share, the most popular continuous mining machines in the world are manufactured by Joy mining (76.1\%), Bucyrus (15.2\%), Sandwik (7.2\%), Fairchild (0.7\%) and Elickhoff (0.5\%).

Other companies also designed or purchased documentation of continuous mining excavators, but implementation into production depends on the profitability and competitiveness of the market. As examples below are presented machines from Sandvik Mining Construction, Joy Mining Machinery, Caterpilar Inc. and Eickhoff GmbH, as shown in Fig. 2 (brochures accessed 27 May 2017).

On Figure $2 \mathrm{e}$ is presented the numerical model of the continuous miner created by authors, the new feature is that two permanent magnet motors which have $500 \mathrm{~kW}$ total power are located inside of the cutter head. 

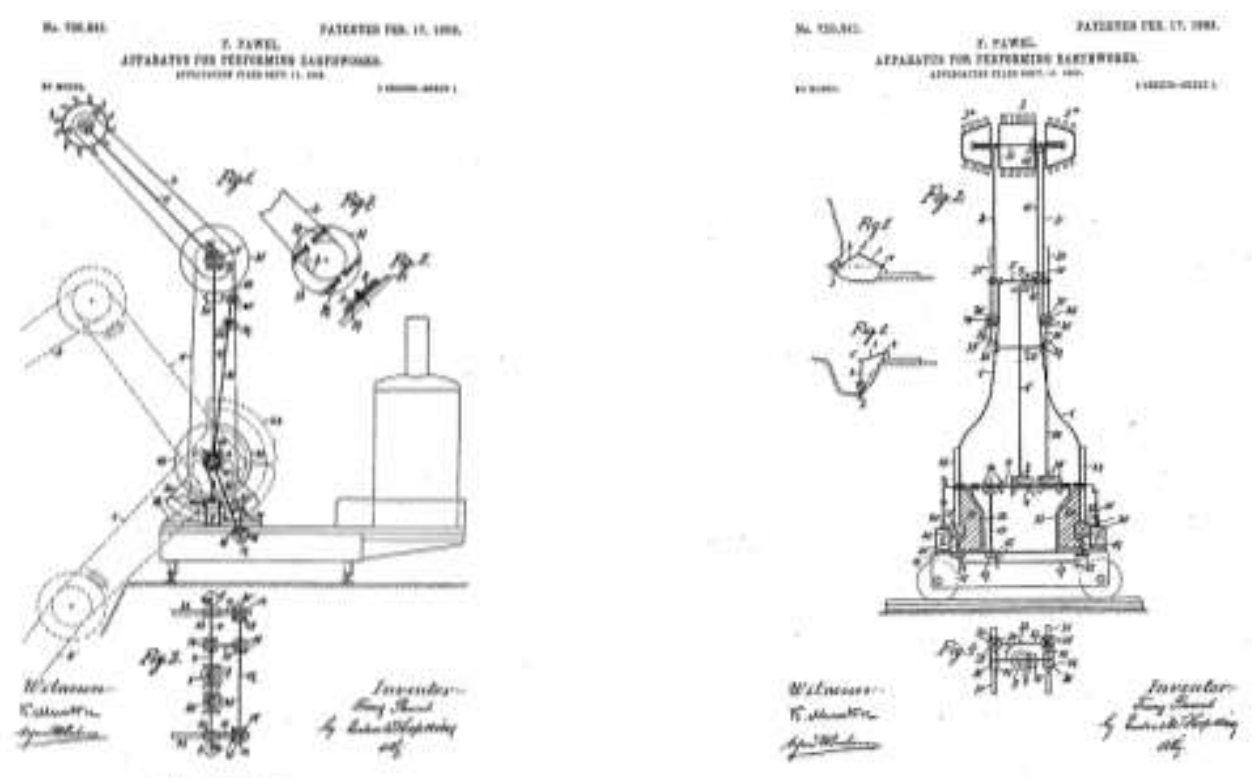

Fig. 1 Example of one of the first patents of Continuous Miner machines: Source: (Pawel) "Apparatus for performing earthworks" - patent US 720841

a)

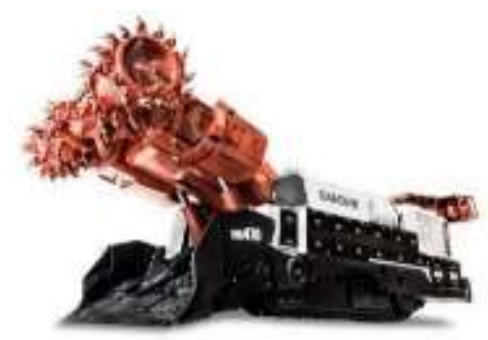

c)

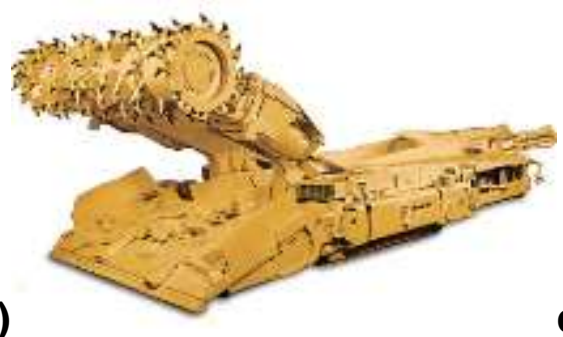

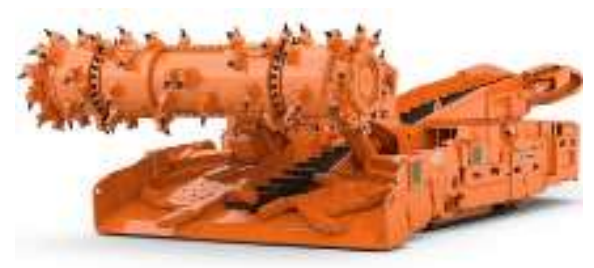

b)
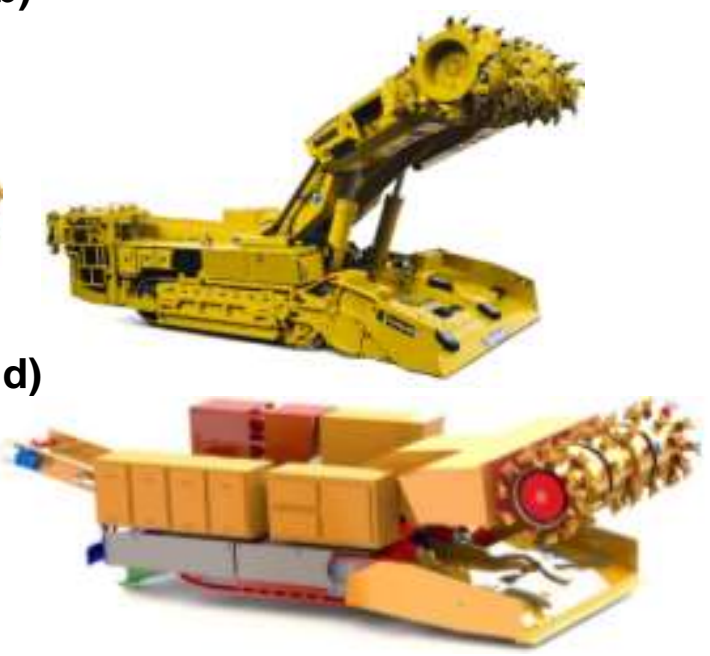

e)

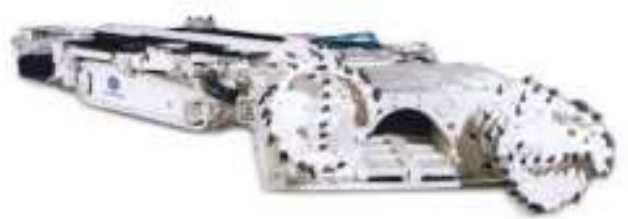

Fig. 2 Overview of various Continuous miners: a) Sandvik MC 470, b) Joy 14CM 27, c) Caterpillar CM445, d) Eickhoff Cm2H-45, e) GE Fairchild F330 (brochures accessed 27 May 2017) f) numerical model of the continuous miner created by authors, two permanent magnet motors located inside of the cutter head

\section{DEVELOPMENT TRENDS IN CONTINUOUS MINERS}

As it was mentioned before, because of the high competition in the mining machinery sector and specific requirements from customers on the global market, some trends in the development of Continuous Miner machines are 
noticeable. Forty-one headlines from various manufacturers were analysed for the presentation of the trends. The analysis of the data from official websites (brochures accessed 27 May 2017) included compilation and statistical comparison of geometrical and kinematic parameters of the cutting process, energy parameters and the power of installed engines. The geometric parameters taken into account, refer to the minimum and maximum cutting height, width and diameter of the cutting head, and also the total weight of the machine. It must be remembered that the energy parameters refer to the total power of the engines installed in the head and the power of the engines in the cutting unit. Results were presented in a shortened version by Mężyk et al in 2019 , below are presented extended results. Figure 3 presents a comparison of 41 Continuous Miner's minimum and maximum cutting height, cutting width and cutter drum diameter.

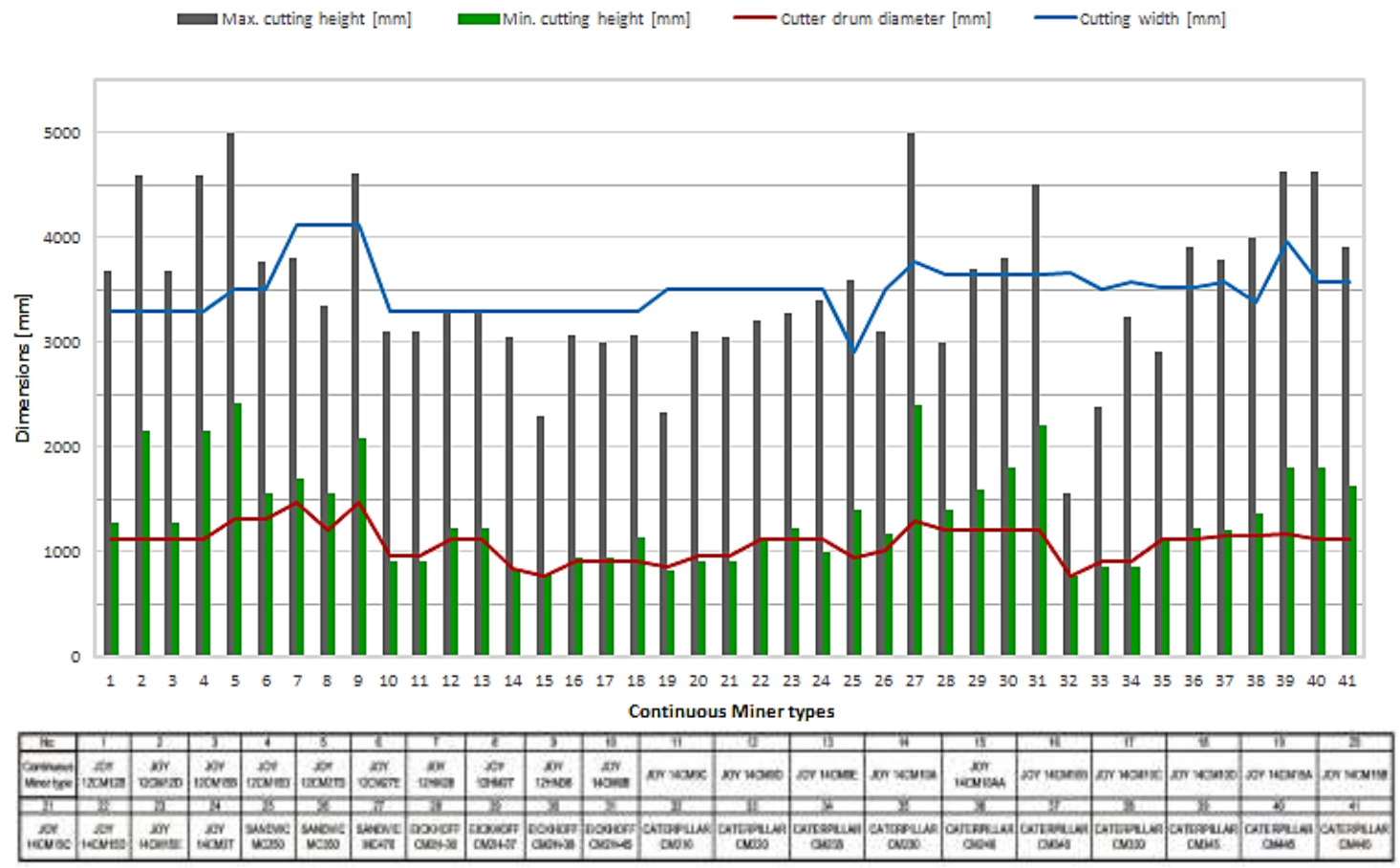

Fig. 3 Comparison of Continuous Miners min. and max. cutting height, cutting width and cutter drum diameter

In Figure 3 can be noticed that the minimum cutting height is closely related to the cutting head geometry. The trend line in Figure 4a indicates that an increase in the diameter of the cutting head depends on the maximum and minimum cutting height. The maximum cutting height is parameter dependent on the boom construction form. In heavier machines with higher cutter drum power and diameter higher ranges of cutting height is noticeable (Figure $4 a, 4 c, 4 d$ ). The cutting width in presented continuous miners is between $2900 \mathrm{~mm}$ to $4115 \mathrm{~mm}$. The energy parameters of the analysed heads are presented in Figure 5 . The relation between the weight of continuous miner and the power of the engines is noticeable. 
a)
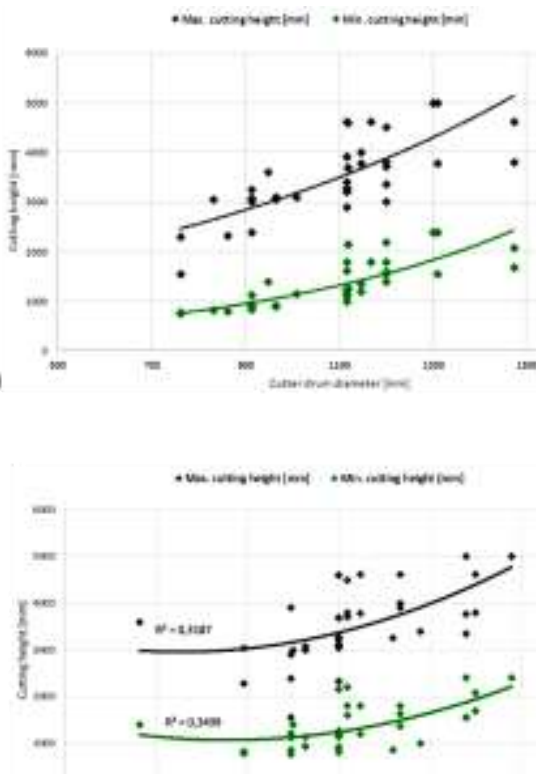

c)
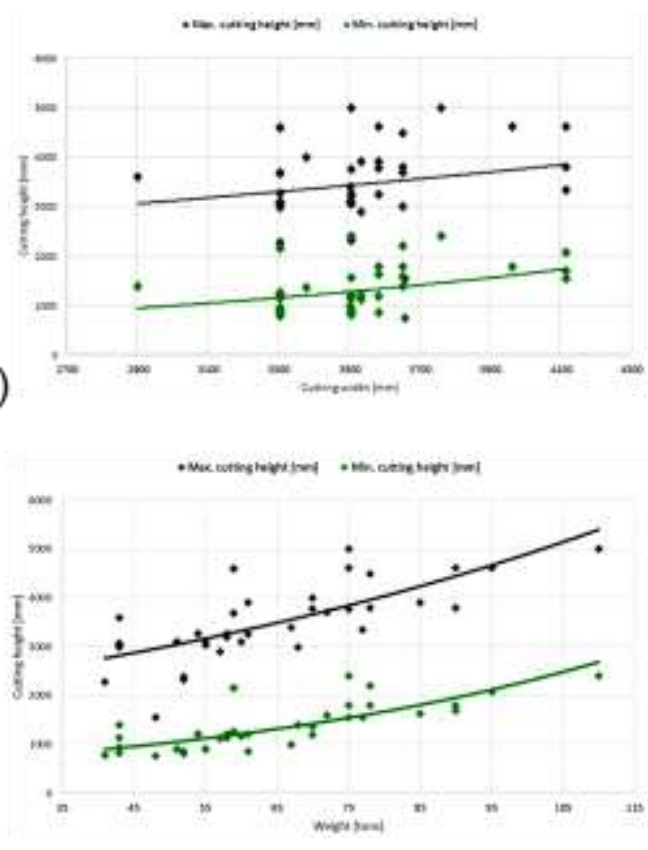

Fig. 4 Trends between: a) cutter drum diameter vs. cutting height, b) cutting width vs. height, c) cutter drum power vs. cutting height, d) weight vs. cutting height

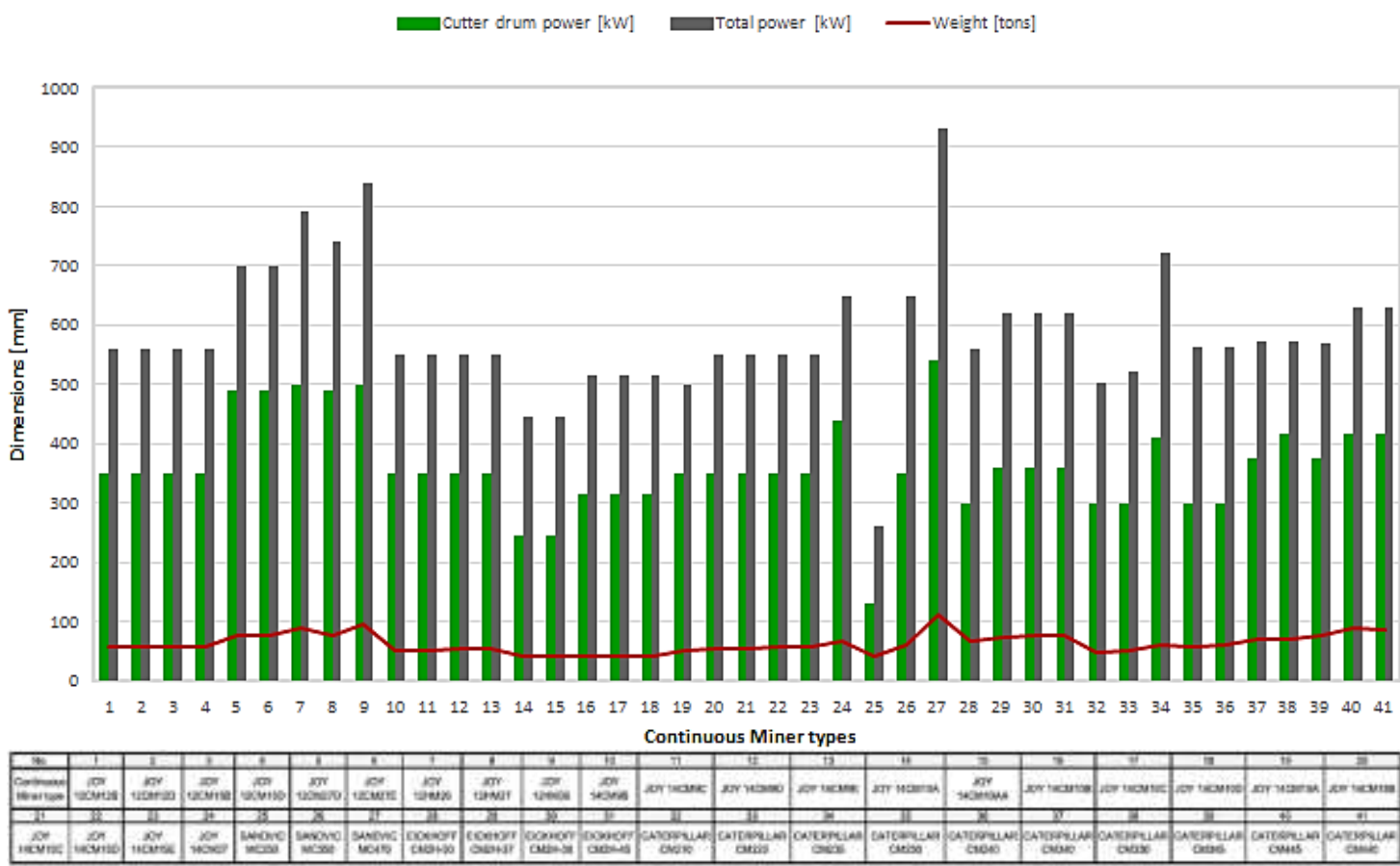

Fig. 5 Comparison of Continuous Miners cutter drum power, total power and weight

Detailed visualisation of the power of the engines to weight ratio is presented in Fig. 6a. Statistical analysis carried out by linear approximation showed that for the analysed headers the power density factor is on average $0.12 \mathrm{~kW} / \mathrm{ton}$, with the ratio of the total power of installed engines to the power of the cutting head drive 0.64 , as shown in Figure $6 \mathrm{~b}$. Figure $6 \mathrm{c}$ shows weight and the total power of analysed continuous miners. 


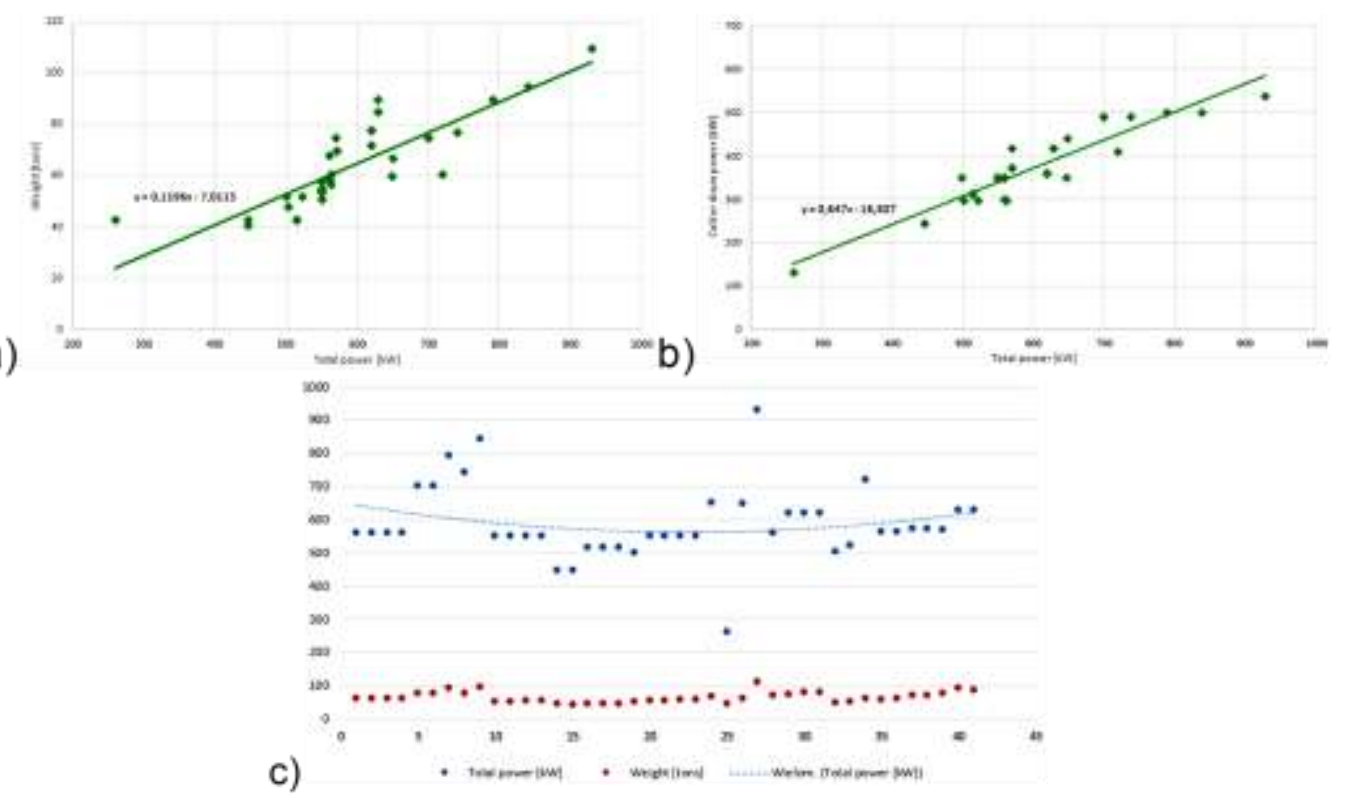

Fig. 6 Relationship between:

a) total power and total power, b) total power and cutter drum power,

c) Total power and weight of $\mathbf{4 1}$ analysed continuous miners

Figure 7a shows the power of the motors used to drive the drum in a function of the angular speed of the cutter drum. Must be noticed that for all analysed machines is required a constant driving moment necessary for rock extraction. From the slope factor of the trend line, was determined the average value of the driving torque equal $34377 \mathrm{Nm}$.

a)

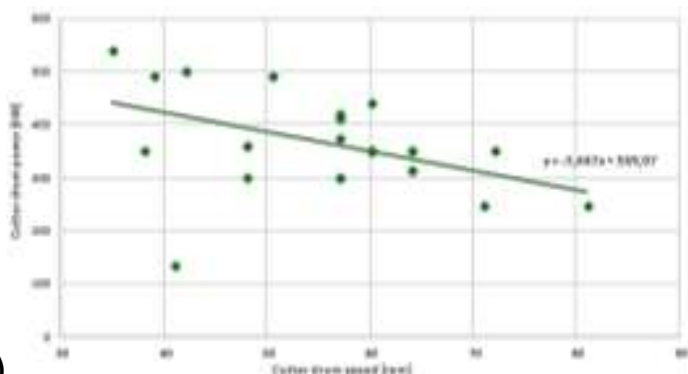

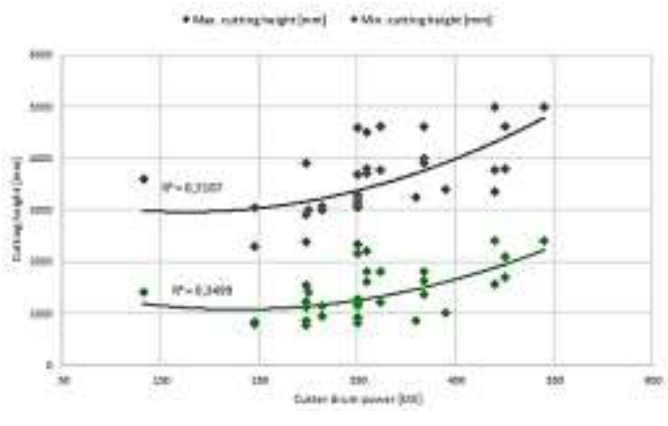

b) between:

a) cutter drum speed and cutter drum power, b) cutter drum power and cutting height

Interesting is also a correlation between motor power values of the cutting head and the minimum and maximum cutting height, presented in Figure $7 \mathrm{~b}$. The large dispersion of points with the trend line expressed by a square of the correlation coefficient of $34 \%$ for the minimum cutting height and $31 \%$ for the maximum cutting height confirm, that influence of the cutting height on power demand is insignificant.

\section{TRENDS IN CONTINUOUS MINER CUTTER DRUM POWERTRAIN SYSTEMS}

The patent analysis in global databases (USPT, USAPP, EP, WIPO, JP, DE) was limited to a specific ICP classification (E21 - FIXED CONSTRUCTIONS - 
EARTH DRILLING; MINING). Additionally, the keyword "Continuous Miner" was specified, and it was found that the number of patents for new design solutions in Continuous Miner machines was rapidly increasing.

Due to a large number of patents and their diversity, it was decided that the discussion will cover patents in the field of transmission of the cutting head drive, in particular using electric motors located inside the cutting head body. For this reason, the search field has been narrowed down by using the keywords 'drum' and 'driver' present in the patent summary, which helped reduce the number of patents available to 25 entries. However, when searching the cited patent publications in this group of patents, some of them do not use the keyword "Continuous Miner".

Table 1 presents a chronological summary of patent solutions in the field of power transmission. They relate to both the location of the propulsion engines and the design solutions of the cutting head drive gear.

Table 1 Patents for the modular drive system of the cutting head

\begin{tabular}{|c|c|c|c|}
\hline $\begin{array}{c}\text { Date } \\
\text { of publication }\end{array}$ & Patent title & $\begin{array}{c}\text { Patent } \\
\text { number }\end{array}$ & Ownership \\
\hline 1 & 2 & 3 & 4 \\
\hline 1966 & $\begin{array}{l}\text { Motorised multiple drums } \\
\text { for mining machine }\end{array}$ & $\begin{array}{c}\text { US } \\
3290096\end{array}$ & $\begin{array}{c}\text { WESTINGHOUSE AIR } \\
\text { BRAKE CO }\end{array}$ \\
\hline 1967 & $\begin{array}{c}\text { Mining apparatus } \\
\text { supporting } \\
\text { and driving construction }\end{array}$ & $\begin{array}{c}\text { US } \\
3305273\end{array}$ & $\begin{array}{l}\text { GALION JEFFREY } \\
\text { MFG CO }\end{array}$ \\
\hline 1976 & $\begin{array}{c}\text { Continuous mining machine } \\
\text { with } \\
\text { a chain drive for } \\
\text { the cutting head }\end{array}$ & $\begin{array}{c}\text { US } \\
3968995\end{array}$ & $\begin{array}{c}\text { DRESSER } \\
\text { INDUSTRIES, INC. }\end{array}$ \\
\hline 1977 & $\begin{array}{c}\text { Mining machine with cutter } \\
\text { drum having an internal } \\
\text { drive }\end{array}$ & $\begin{array}{c}\text { US } \\
4047763\end{array}$ & $\begin{array}{c}\text { JOY } \\
\text { MANUFACTURING } \\
\text { COMPANY } \\
\end{array}$ \\
\hline 1980 & $\begin{array}{c}\text { Apparatus } \\
\text { for interconnecting } \\
\text { segmented cutter drums of a } \\
\text { rotary cutter mechanism }\end{array}$ & $\begin{array}{c}\text { US } \\
4190296\end{array}$ & $\begin{array}{c}\text { DRESSER } \\
\text { INDUSTRIES, INC. }\end{array}$ \\
\hline 1992 & $\begin{array}{c}\text { Drum assembly } \\
\text { for a Continuous Miner }\end{array}$ & $\begin{array}{c}\text { US } \\
5143423\end{array}$ & $\begin{array}{c}\text { TAMROCK WORLD } \\
\text { CORP }\end{array}$ \\
\hline 1982 & $\begin{array}{c}\text { Cutter drum assembly } \\
\text { for a continuous mining } \\
\text { machine }\end{array}$ & $\begin{array}{c}\text { US } \\
4310199\end{array}$ & $\begin{array}{l}\text { NATIONAL MINE } \\
\text { SERVICE COMPANY }\end{array}$ \\
\hline 1986 & $\begin{array}{c}\text { Drive assembly } \\
\text { for mining machine cutter } \\
\text { drum }\end{array}$ & $\begin{array}{c}\text { US } \\
4582363\end{array}$ & $\begin{array}{l}\text { NATIONAL MINE } \\
\text { SERVICE COMPANY }\end{array}$ \\
\hline 1992 & $\begin{array}{c}\text { Drum assembly } \\
\text { for a Continuous Miner }\end{array}$ & $\begin{array}{c}\text { GB } \\
2251878 \mathrm{~A} \\
\end{array}$ & $\begin{array}{l}\text { TAMROCK WORLD } \\
\text { CORPORATION N V }\end{array}$ \\
\hline 1999 & $\begin{array}{c}\text { Apparatus } \\
\text { for mining } \\
\text { a mineral seam } \\
\end{array}$ & $\begin{array}{c}\text { US } \\
5964507\end{array}$ & $\begin{array}{c}\text { MINING } \\
\text { TECHNOLOGIES, INC. }\end{array}$ \\
\hline 2005 & $\begin{array}{l}\text { Drum turning mechanism } \\
\text { For Continuous Miners and } \\
\text { longwall shearers }\end{array}$ & $\begin{array}{c}\text { US } \\
2005 / 0206216\end{array}$ & $\begin{array}{l}\text { JOY MM DELAWARE, } \\
\text { INC. }\end{array}$ \\
\hline 2012 & $\begin{array}{l}\text { A cutter head containing } \\
\text { its motors } \\
\text { and gearcase }\end{array}$ & $\begin{array}{c}\text { US } \\
8235470\end{array}$ & $\begin{array}{l}\text { JOY MM DELAWARE, } \\
\text { INC. }\end{array}$ \\
\hline
\end{tabular}

Source: (Mężyk et al., 2019. http://www.google.com/patents/, http://worldwide.espacenet.com/) 
Other interesting source of knowledge about patents is WIPO (World intellectual property organization), where for all countries and languages with publication dates between 2011-2019, the keyword "EN_TI:(CONTINUOUS MINER)" in the title gave 145 results (https://patentscope.wipo.int/search/en/search.jsf), most of them under international class IPC E21C (Earth or rock drilling; mining; mining or quarrying).
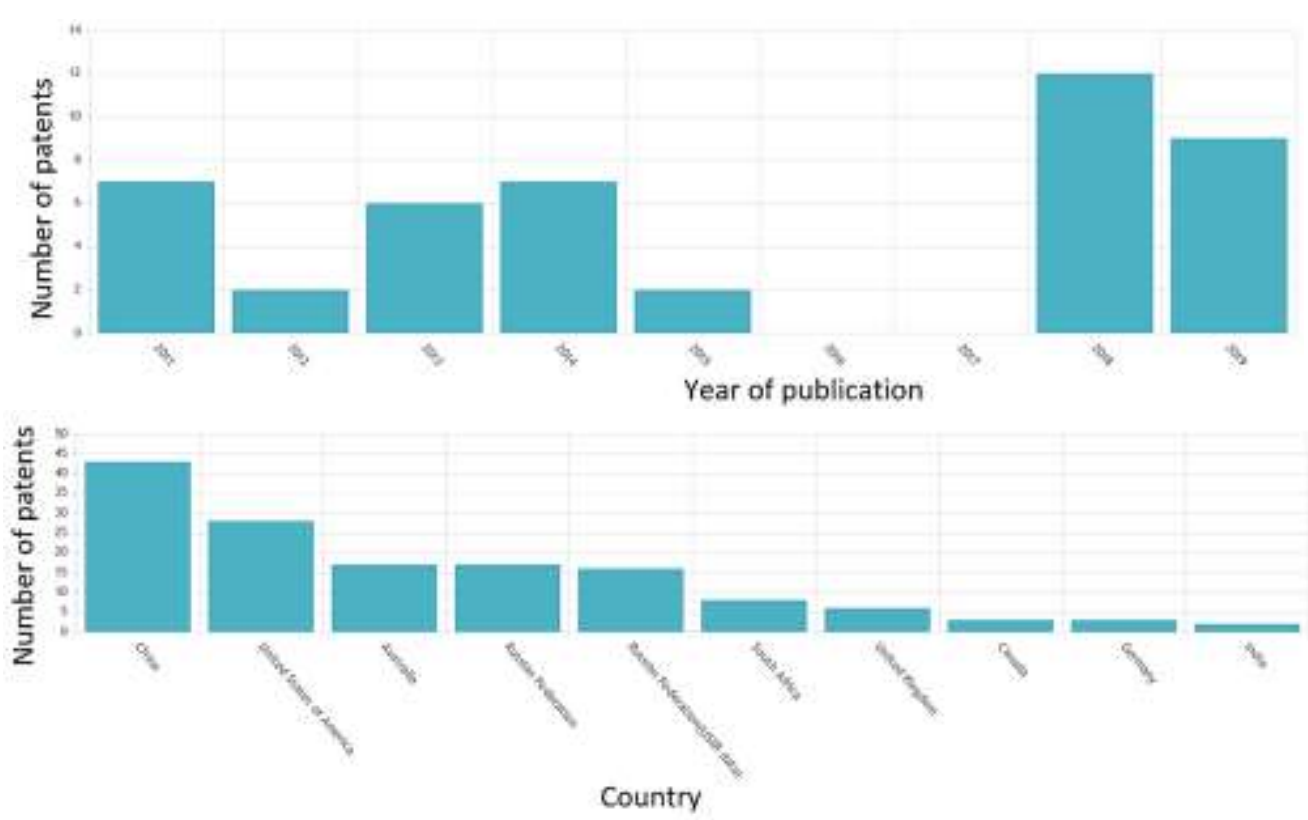

Fig. 8 Number of Continuous Miners patents in a function of years Source: (patentscope.wipo.int)

From the Table 1 can be found, that designers already in the 1960s noticed the advantages of introducing electric motors into the cutting head body. Unfortunately, the technology and low power density did not allow to apply it to continuous miners working under heavy load conditions. Example patents are presented in Figures 9a and 9b.

a)

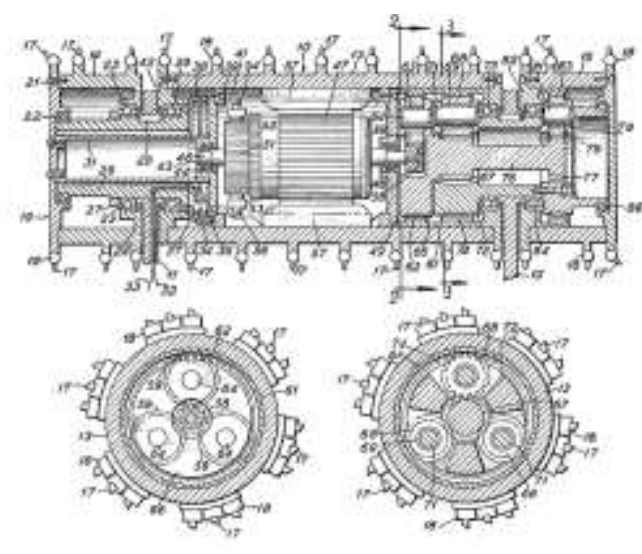

Fig. 9 Powertrain system of cutting drum:

"Motorized multiple drums for mining machine" patent US 3290096

b) "Mining machine with cutter drum having internal drive" patent US 4047763 
The new solution appeared in this field In the 1990s. There was still impossible to receive sufficient power density from the electric motors, but it was compensated by mounting them on the boom near the cutting drum (Figs. 10a and 10b). This solution had many advantages compared to the systems with the engines located on the chassis of the header.

a)

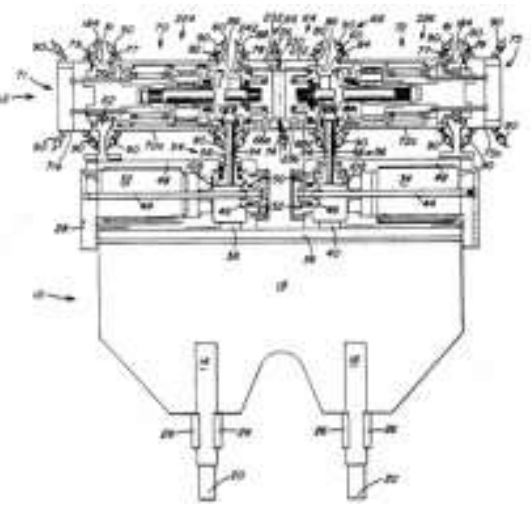

b)

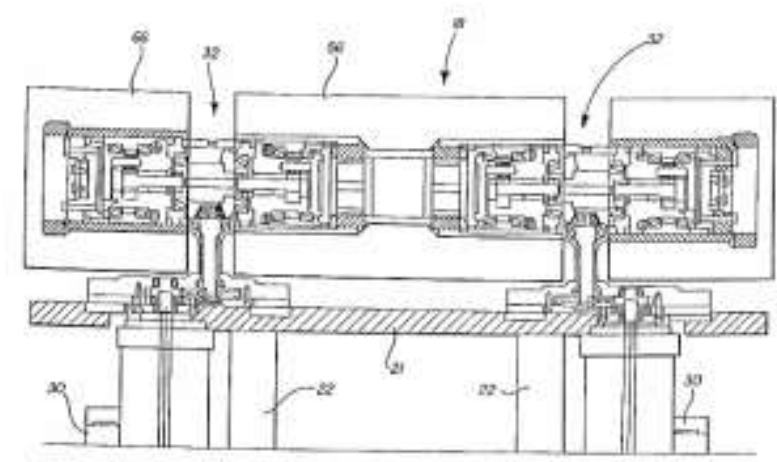

Fig. 10 Example patents for the cutter drum powertrain:

a) "Drum assembly for a Continuous Miner" patent US 5143423

b) "Apparatus for mining a mineral seam" patent US 5964507

Source: (LeBegue et al.,1992, no page), (Blackstock et al.,1999, no page)

In nowadays due to vast progress in electric motors, especially in permanent magnet technology, higher power density is received and make it possible to return to the concept of placing them in a cutting drum (Wang et al., 2009, p. 249; Xiao, Wang and Zhang, 2008, p. 361; Minav et al., 2012, p. 506; Lin et al., 2010, p. 11; Hui and Junging, 2010, p. 213). Such a concept is applied in the patent presented in Fig. 11, in which authors integrated the gear motor on the external sections of the cutting drum.
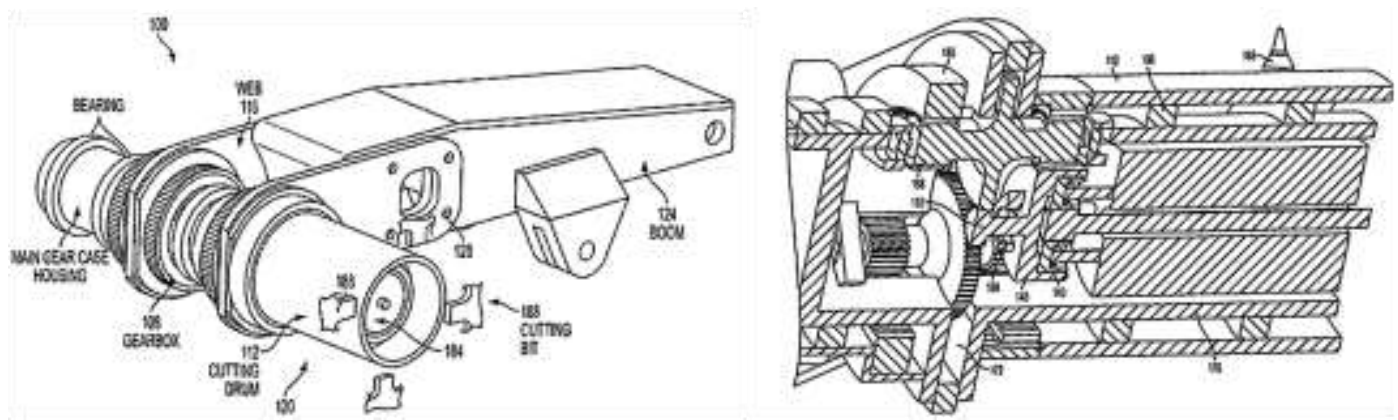

Fig. 11 Power train of cutter drum:

"A cutter head containing its motors and gearcase" patent US 8235470 Source: (Zimmerman and Lowman, 2012)

In a publication from 2019, Mężyk et al presented a modular structure of the cutting drum with integrated PMSM motors (Figure 12). Results from numerical simulations and tests were very promising, and the torque from the permanent magnet motors connected by double reduction planetary gearbox was sufficient. Solutions for tunnel mining machine with linear mining, digging unit of a tunnel digging machine with linear digging and finally system and method of vibration 
reduction in drilling or digging machines were patented (Mężyk et al.) and results of the research were published (Mężyk et al.).

The cutting drum (Figure 12), is characterised by drive units (1) couplings (2) planetary gearboxes (3) the load-bearing supports (4) the body of the cutting drums $(5,6)$ and the boom body $(7)$

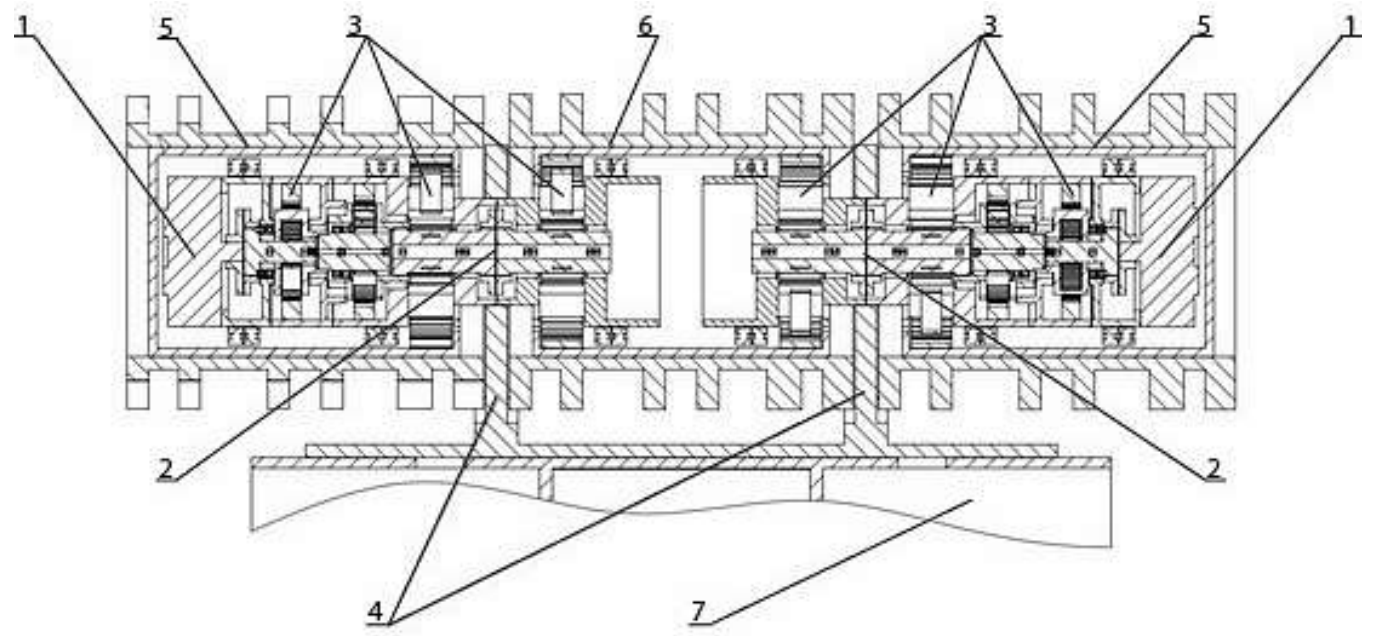

Fig. 12 A modular drive of the cutting head of a Continuous Miner Source: (Mężyk et al.)

The modular drive system allows its placement into the cutting heads along the axis of rotation, avoiding necessary transmission of the drive torque along the boom body of the Continuous Miner. Such solution allows increasing the width of cutting and the power of the drive by adding more modules, and decreasing the cross-section of the cutting heads supports and thus the cutting head passive area. By elimination of the drive transmission system components the stiffness of the cutting drum supports is higher and the dynamic performance of the boom is improved by reduced vibration influence (Hurt, MacAndrew and Morris, 1988, p. 236; Mężyk et al.).

\section{CONCLUSION}

As it was mentioned in previous chapters, nowadays constructions of continuous miner machines are the result of rather an evolution than revolution. The designs of this type of header have been evolving for more than 100 years. Throughout this time, other technologies also developed, but could not be used in the former designs due to their lack of advancement. An excellent example of this is the development of cutting head designs with electric motors, as described in the article, which was not used in industrial application. The growing trend visible in the number of newly-published patents referring to Continuous Miner machines is reflected in the types of deposits that are currently being manufactured and scheduled for exploitation.

The analyses carried out by the authors and development trends confirm that the modular drive system allows its placement into the cutting heads along the axis of rotation, avoiding necessary transmission of the drive torque along the boom body of the Continuous Miner. Such a solution allows increasing the width 
of cutting and the power of the drive by adding more modules, and decreasing the cross-section of the cutting heads supports and thus the cutting head passive area. Statistical analysis carried out by linear approximation showed that the power density factor for the analysed headers is on average 0.12 $\mathrm{kW} /$ ton, while the factor determining the total power of installed engines to the power of the cutting head drive is 0.64 . In all the analysed cases, the cutting width is an independent parameter in relation to the boom kinematics and ranges from $2900 \mathrm{~mm}$ to $4115 \mathrm{~mm}$. The averaged value of the driving torque for the analysed cases was $34377 \mathrm{Nm}$. The large dispersion of points with the trend line expressed by a square of the correlation coefficient of $34 \%$ for the minimum cutting height and $31 \%$ for the maximum cutting height confirm, that influence of the cutting height on power demand is insignificant. The concept of the modular design of the cutting drum can be attractive for manufacturers, but further improvements in PMSM engines must be applied by reducing the costs and increasing its power density.

\section{ACKNOWLEDGEMENTS}

The authors gratefully acknowledge funding by the National Science Centre, Poland, under the 3383/B/T02/2011/40 grants.

\section{REFERENCES}

ANON, Middlebult mines sires new Joy miner, ANON, Coal, 99(10), 1994, pp 74,76-77, International Journal of Rock Mechanics and Mining Sciences \& Geomechanics Abstracts, Volume 32, Issue 3, April 1995, Page A121, ISSN 0148-9062

C. Balci, Correlation of rock cutting tests with field performance of a TBM in a highly fractured rock formation: a case study in Kozyatagi-Kadikoy Metro Tunnel, Turkey Tunn. Undergr. Sp. Technol., 24 (2009), pp. 423-435

Jon C. Blackstock, John A. Baird, Jr., lan T. Carr, Apparatus for mining a mineral seam, patent: US 5964507 A 1999

Brochures Available at: http://www.miningandconstruction.sandvik.com/(Accessed: 27 May 2017)

Brochures Available at: http://www.joy.com/ (Accessed: 27 May 2017)

Brochures Available at: https://mining.cat.com/continuous-miners/(Accessed: 27 May 2017)

Brochures Available at: http://www.eickhoff.co.za/ (Accessed: 27 May 2017)

Brochures Available at: https://gefairchild.com (Accessed: 27 May 2017)

Peter Darling, SME Mining Engineering Handbook, Third Edition, 2011

M.W.J. Graham, Developments and trends in miners/bolters, Mining Technology, 77(887), 1995, pp. 213-217, International Journal of Rock Mechanics and Mining Sciences \& Geomechanics Abstracts, Volume 33, Issue 1, January 1996, Pages A31-A32, ISSN 0148-9062

J. Gilliland, F. Kendrick, Mining machine with cutter drum having internal drive motors. patent: US 4047763, 1977

S. Hui, J. Junqing, Research on the system configuration and energy control strategy for parallel hydraulic hybrid loader. Journal Automation in Construction, vol. 19 (2010)., no. 2, pp. 213-220

K.G. Hurt, K.M. MacAndrew, C.J. Morris, Boom road header cutting vibration: measurement and prediction, Proc CARE 88 (Conference of Applied Rock Engineering), Newcastle, 6-8 January 1988P89-97. Publ London: IMM, 1988, International Journal of Rock Mechanics and Mining Sciences \& Geomechanics Abstracts, Volume 25, Issue 5, October 1988, Page 236, ISSN 0148-9062, 
S. Kenneth, Motorized multiple drums for mining machine, patent: US 3290096, 1966

M. LeBegue, J. Blackstock, H. Woodford II, Clarence, L. Sanders, Drum assembly for a Continuous Miner, patent: US 5143423 A, 1992

T. Lin, Q. Wang, B. Hu, W. Gong, Development of hybrid powered hydraulic construction machinery. Journal Automation in Construction, vol. 19 (2010). no. 1, pp. $11-19$

T. Minav, A. Virtanen, L. Laurila, J. Pyrhönen, Storage of energy recovered from an industrial forklift. Journal Automation in Construction, vol. 22 (2012), p. 506-515,

McFeat-Smith, Considerations for mechanised excavation of rock tunnels, I Proc $6^{\text {th }}$ Australian Tunnelling Conference, Melbourne, March 1987V1, pp. 149-157. Publ Parkville: AusIMM, 1987, International Journal of Rock Mechanics and Mining Sciences \& Geomechanics Abstracts, Volume 26, Issue 5, September 1989, Page 254, ISSN 0148-9062

Mężyk, W. Klein, M. Pawlak, J. Kania, K. Basiura, System and method of vibration reduction in drilling or digging machines (in polish), patent: PL228265B1, 2018

A. Mężyk, J. Kania, M. Pawlak, W. Klein, K. Basiura, Digging unit of a tunnel digging machine with linear digging (in polish), patent: PL225112B1, 2017

A. Mężyk, J. Kania, M. Pawlak, W. Klein, D. Gasiorek, K. Basiura, Tunnel mining machine with linear mining (in polish), patent: PL224769B1, 2017

A. Mężyk, M. Pawlak, J. Kania, W. Klein, A new concept of vibration-control system in continuous miner machine, Adv. Mech. Eng. 2019, vol. 11 iss.1, pp.1-14

A. Mężyk, W. Klein, M. Pawlak, J. Kania, The identification of the vibration control system parameters designed for continuous miner machines, Int. J. Non-Linear Mech. 2017 vol.91, p.181-188

A. Mężyk, W. Klein, M. Fice, M. Pawlak, K. Basiura, Mechatronic model of continuous miner cutting drum driveline, Mechatronics 2016 vol.37, pp.12-20

F. Pawel, Apparatus for performing earthworks, patent: US 720841 A, 1903

Patents Available at: http://worldwide.espacenet.com/ (Accessed: 27 May 2017)

Patents available at: http://www.google.com/patents/ (Accessed: 27 May 2017)

D.Y. Wang, C. Guan, S.X. Pan, M.J. Zhang, X. Lin, Performance analysis of hydraulic excavator power train hybridisation, Automation in Construction 18 (3) (2009) pp. 249-257

Q. Xiao, Q.F. Wang, Y.T. Zhang, Control strategies of power system in hybrid hydraulic excavator, Automation in Construction 17 (4) (2008) pp. 361-367.

J. Zimmerman, G. Lowman, Cutter head containing its motors and gearcase, patent: US 8235470, 2012

\begin{abstract}
.
In this paper is presented the overview of Continuous Miners available on the market. Numbers describe machines from 1 to 41 and parameters obtained from manufacturers catalogues are presented on diagrams. The statistical analysis of some of parameters are carried out by linear approximation to show factors determining, for example, the total power of installed engines to the power of the cutting head drive, the total power of installed engines to the total mass, cutting height to the cutter diameter and cutting height to the cutting width, etc. Thin layers of coal less than $1.2 \mathrm{~m}$ thick and remnants of seams that require work on a system of boards and columns constitute an increasing share of coal deposits. Geometric restrictions, in this case, are closely correlated with the construction form of the machine and they must have high performance with limited geometric dimensions. This type is called "Continuous Miner", and is closely correlated with those restrictions. The paper reviews the technical solutions used in these machines, which are currently used around the world. Particular attention is paid to the new concept of the cutting drum drive system, in which permanent magnet motors are proposed. Placing them in a cutting drum improves the efficiency of the mining process and the possibility of modular configuration depending on the required working conditions.
\end{abstract}

Keywords: continuous miner, road header machine, permanent magnet motor 